\title{
Cyclic changes in gene expression induced by Peg-interferon alfa-2b plus ribavirin in peripheral blood monocytes (PBMC) of hepatitis C patients during the first 10 weeks of treatment

\author{
Milton W Taylor*1, Takuma Tsukahara1, Jeanette N McClintick², \\ Howard J Edenberg ${ }^{2}$ and Paul Kwo ${ }^{3}$
}

Address: ${ }^{1}$ Department of Biology, Indiana University, Bloomington, IN. 47401, USA, ${ }^{2}$ Department of Biochemistry and Molecular Biology and Center for Medical Genomics, Indiana University School of Medicine, Indianapolis, IN 46202, USA and ${ }^{3}$ Department of Medicine, Hepatology Unit, Indiana University School of Medicine, Indianapolis, IN 46202, USA

Email: Milton W Taylor* - taylor@indiana.edu; Takuma Tsukahara - kobestory@hotmail.com; Jeanette N McClintick - jnmcclin@iupui.edu; Howard J Edenberg - edenberg@iupui.edu; Paul Kwo - pkwo@iupui.edu

* Corresponding author

Published: 5 November 2008

Journal of Translational Medicine 2008, 6:66 doi:10.1 186/1479-5876-6-66
Received: 16 September 2008

Accepted: 5 November 2008

This article is available from: http://www.translational-medicine.com/content/6/1/66

(C) 2008 Taylor et al; licensee BioMed Central Ltd.

This is an Open Access article distributed under the terms of the Creative Commons Attribution License (http://creativecommons.org/licenses/by/2.0), which permits unrestricted use, distribution, and reproduction in any medium, provided the original work is properly cited.

\begin{abstract}
Background and Aims: This study determined the kinetics of gene expression during the first 10 weeks of therapy with Pegylated-interferon-alfa2b (PegIntron ${ }^{\mathrm{TM}}$ ) and ribavirin (administered by weight) in $\mathrm{HCV}$ patients and compared it with the recently completed Virahep $C$ study $[1,2]$ in which Peginterferon-alfa2a (Pegasys ${ }^{\mathrm{TM}}$ ) and ribavirin were administered.

Methods: RNA was isolated from peripheral blood monocytes (PBMC) from twenty treatment-naïve patients just before treatment (day I) and at days 3, 6, I0, 13, 27, 42 and 70 days after treatment. Gene expression at each time was measured using Affymetrix microarrays and compared to that of day $I$.

Results: The expression of many genes differed significantly ( $\mathrm{p} \leq 0.00 \mathrm{I}$ and changed at least 1.5 -fold) at days 3 (290 probes) and 10 (255 probes), but the number dropped at days 6 (165) and 13 (142). Most genes continued to be up regulated throughout the trial period. A second group of genes, including CXCLIO, CMKLRI (chemokine receptor I), TRAIL, ILIR $\alpha$ and genes associated with complement and lipid metabolism, was transiently induced early in treatment. CDKNIC (cyclin kinase inhibitor I) was induced early but repressed at later times. Genes induced at later times were mostly related to blood chemistry and oxygen transport. By week 10, II of the patients demonstrated a positive response to therapy, and the final sustained viral response (SVR) was 35\%. The levels of gene induction or decrease was very similar to that previously reported with Pegasys/ribavirin treatment.

Conclusion: The response to Pegintron/ribavirin was similar to that reported for Pegasys/ribavirin despite some differences in the amount administered. We did not detect major differences at the genomic level between patients responding to treatment or non-responders, perhaps because of limited power. Gene induction occurred in a cyclic fashion, peaking right after administration of interferon and declining between administrations of the drug. Our data suggest that more than once a week dosing might be desirable early during treatment to maintain high levels of response as measured by gene expression.
\end{abstract}




\section{Background}

Hepatitis C virus (HCV) infection is a significant global public health problem, affecting approximately 200 million individuals in the world and over 4 million in the United States alone, where it is the most prevalent bloodborne infection [3]. It is currently the leading indication for a liver transplant and is responsible for 8,000-10,000 deaths annually. Interferon (IFN) has formed the backbone of therapy against HCV, first as monotherapy, then in combination with the nucleoside analogue ribavirin [4]. Current standard of care for chronic HCV infection consists of a regimen of pegylated interferon- $\alpha$ in combination with ribavirin. The addition of the polyethylene glycol (PEG) moiety (pegylation) increases the half-life of the IFN molecule and has facilitated once per week dosing instead of the two or three doses per week previously required with non-pegylated forms of IFN $[5,6]$. The combination of pegylated IFN- $\alpha$ and ribavirin successfully eradicates the virus from $50-60 \%$ of those treated $[7,8]$.

Two different pegylated molecules of IFN have been approved for clinical use in the U.S. The size and position of the PEG moiety differs between pegylated-interferon- $\alpha$ 2a (Pegasys $^{\mathrm{TM}}$ ) and Pegylated-interferon- $\alpha-2 \mathrm{~b}$ (PegIn$\left.\operatorname{tron}^{\mathrm{TM}}\right)[5,9,10]$. Although pegylation improves the pharmacokinetic properties of the core IFN protein [11], it decreases the in vitro biological activity $[12,13]$. PegIntron $^{\mathrm{TM}}$ has higher in vitro anti-viral activity than Pegasys ${ }^{\mathrm{TM}}$ $[11,14,15]$ (Taylor, unpublished data).

Type I IFNs do not directly inactivate the virus, but exert their effects through binding to specific receptors on the cell surface, IFNAR1 and IFNAR2 [16]. This results in a cascade of gene activation through the Jak-STAT pathway [17-19] and perhaps other transcription pathways $[20,21]$. Large number of genes are induced or down regulated by non-pegylated IFNa in vitro [22-25]. Previous work [15] has shown very similar in vitro profiles of gene induction in monocytes (PBMC) treated with either pegylated or the non-pegylated version of IFNa. Virtually all of the changes in gene expression were due to the IFN, rather than the ribavirin [23]. We have recently reported that the expression of many hundreds of genes are significantly modified, both up and down, in vivo following treatment of hepatitis $\mathrm{C}$ patients with pegylated-IFN $\alpha-2 \mathrm{a}$ (Pegasys $^{\mathrm{TM}}$ ) and ribavirin [2]. Using a mathematical model we identified a core set of genes that appear to be related to the anti-viral effects. These include OAS2, MX1, MX2, RIG1, genes associated with ubiquitination, and many other genes previously shown to be associated with interferon treatment [26].

In this report we analyze the response of patients to combination treatment with pegylated-interferon- $\alpha_{2 b}$ (PegIn$\left.\operatorname{tron}^{\mathrm{TM}}\right)$ and ribavirin during the first 10 weeks of treatment. Unlike the previous report from the Virahep C study [2], which used a constant dose of 180 ug of pegylated-interferon- $\alpha-2 a$, in the present study the PegIntron $^{\mathrm{TM}}$ was administered in an amount related to the body weight of the patients. Blood samples were collected before treatment initiation (day 1) and at days 3, 6, 10, $13,27,42$ and 70 after treatment. Interferon injections were weekly at day $1,7,14$ etc. The selection of days was based on times just before interferon injection (days 6,13, 27,42 and 70) in order to analyze whether there was a trough in gene expression at the end of the weekly period. Affymetrix microarrays were used to detect genes up- or down- regulated during treatment. Viral assays for the presence of HCV in serum were performed at the same time points. In this study we report that changes in gene expression levels are high 3 days after IFN injection and return toward baseline before the next injection; the return toward baseline is accompanied in many cases by a slight increase in virus titer. This pattern continues for the first few weeks. Genes induced by the treatment fall into three classes, genes that are up regulated throughout the treatment, immediate expressed genes with only transient expression, and late genes in which expression is elevated only after day 27 . Fifty percent of the patients showed an antiviral response during the first 10 weeks, but the final SVR was $35 \%$.

\section{Materials and methods Subjects}

Twenty (16 M, $4 \mathrm{~F}$ ) genotype 1 hepatitis $C$ patients who gave informed consent were entered into this trial. All subjects were previously untreated, and had no other cause of chronic liver disease, ALT levels above the upper limit of normal, compensated liver disease with minimal hematological parameters including hemoglobin values of 12 $\mathrm{gm} / \mathrm{dL}$ for females and $13 \mathrm{gm} / \mathrm{dL}$ for males, WBC $>3,000 /$ $\mathrm{mm}^{3}$, neutrophil count $>1,500 / \mathrm{mm}^{3}$, platelets $>70,000 /$ $\mathrm{mm}^{3}$ and no evidence of decompensation in those with cirrhosis. All patients had liver biopsies within 3 years of enrolling, with fibrosis graded by the Metavir scoring system. Patients were excluded if they had decompensated cirrhosis, serum $\alpha$-fetoprotein concentration above $50 \mathrm{ng} /$ L, HIV infection, previous organ transplantation, other causes of liver disease, pre-existing psychiatric disease, seizure disorders, cardiovascular disease, haemoglobinopathies, haemophilia, poorly controlled diabetes, or autoimmune-type disease, or if they were unable to use contraception. Table 1 presents the demographics of the population used in this study. This study was approved by the institutional review board.

Patients received PegIntron ${ }^{\mathrm{TM}}$ at $1.5 \mu \mathrm{g} / \mathrm{kg}$ (based upon weight at initial visit) administered subcutaneously once a week for 10 weeks (days 1, 7, 14, 21, $28 \ldots$..), plus ribavirin $(13 \pm 2 \mathrm{mg} / \mathrm{kg} /$ day $)$. Patients had blood drawn for 
Table I: Pretreatment characteristics of the patients

\begin{tabular}{|c|c|c|c|c|c|c|c|}
\hline Patient ID & Age & Weight (kg) & Genotype & Gender & Fibrosis Score Metavir & ALT (IU/L) & Day I HCV RNA level (IU/MI) \\
\hline I & 49 & 76 & la & I & 4 & 74 & $1.7 \mathrm{E}+06$ \\
\hline 2 & 52 & 92 & la & 0 & 0 & 20 & $7.0 \mathrm{E}+05$ \\
\hline 3 & 52 & 92 & $\mathrm{Ia}$ & I & 4 & 57 & $3.4 \mathrm{E}+06$ \\
\hline 4 & 38 & 90 & $\mathrm{la}$ & i & 0 & 52 & $\mathrm{I} . \mathrm{IE}+07$ \\
\hline 5 & 56 & 80 & la & 1 & 2 & 68 & $3.5 \mathrm{E}+06$ \\
\hline 6 & 47 & 106 & la & 1 & 3 & 146 & $\mathrm{I} . \mathrm{IE}+07$ \\
\hline 7 & 44 & 65 & $\mathrm{Ib}$ & I & 2 & 127 & $\mathrm{I} . \mathrm{IE}+07$ \\
\hline 8 & 42 & 112 & la & 1 & 1 & 67 & $7.2 \mathrm{E}+06$ \\
\hline 9 & 52 & 78 & la & I & 4 & 71 & $2.3 E+06$ \\
\hline 10 & 57 & 76 & $\mathrm{Ib}$ & 0 & 2 & 68 & 7. $I E+06$ \\
\hline 11 & 59 & 70 & Ib & 0 & 3 & 62 & $2.4 \mathrm{E}+06$ \\
\hline 12 & 56 & 109 & $\mathrm{la}$ & I & 4 & 74 & $5.8 \mathrm{E}+06$ \\
\hline 13 & 49 & 116 & Ia & I & 2 & 44 & $5.8 E+06$ \\
\hline 14 & 53 & 90 & Ib & I & 4 & 98 & $3.7 E+05$ \\
\hline 15 & 51 & 61 & $\mathrm{la}$ & 0 & 3 & 73 & $1.8 \mathrm{E}+06$ \\
\hline 16 & 50 & 78 & la & 1 & 3 & 99 & $1.6 \mathrm{E}+06$ \\
\hline 17 & 60 & 106 & Ia & I & 2 & 37 & 4. IE+05 \\
\hline 18 & 45 & 114 & Ia & I & 4 & 161 & $9.0 \mathrm{E}+05$ \\
\hline 19 & 47 & 74 & $\mathrm{Ib}$ & I & 3 & 117 & $4.0 \mathrm{E}+05$ \\
\hline 20 & 61 & 83 & $\mathrm{Ib}$ & I & 2 & 181 & 8. $1 E+05$ \\
\hline
\end{tabular}

analysis on day 1 prior to first injection of interferon (base line) and at days 3, 6, 10, 13, 27, 42 and 70.

\section{HCV-RNA Serum Determinations}

Serum samples were collected before treatment initiation (day 1 ) and at days $3,6,10,13,28,42,70$ and weeks 12, 24, 48 and 72, for viral assays. HCV-RNA was determined by qRT-PCR (TaqMan ${ }^{\oplus}$, Schering-Plough Research Institute, Union, NJ) with a lower limit of detection of 29 IU/ $\mathrm{ml}$.

\section{Peripheral Blood Mononuclear Cell (PBMC) Preparation} Blood was collected in sodium heparin-CPT tubes, diluted with an equal volume $(8 \mathrm{ml})$ of phosphate buffered saline (PBS), carefully layered over a $10 \mathrm{ml}$ Ficoll-Hypaque gradient (Amersham/Pharmacia, Piscataway, NJ) and centrifuged at $800 \mathrm{rpm}$ for 20 minutes at room temperature. The buffy coat layer was transferred to a $15 \mathrm{ml}$ RNAse-free tube, diluted with PBS, and centrifuged at $100 \times \mathrm{g}$ for 15 minutes at room temperature. The supernatants were discarded and the PBMC were retained.

\section{RNA Extraction}

The PBMC were lysed in $1 \mathrm{ml}$ of TRI reagent (Molecular Research Center Inc, Cincinnati, OH). The lysate was mixed with 1-Bromo-3-chloropropane (BCP)-phase separation agent for 1 minute, and incubated at room temperature for 15 minutes. After centrifugation for 15 minutes at $12,000 \mathrm{rpm}$ and $4{ }^{\circ} \mathrm{C}$, RNA was precipitated from the supernatant overnight at $-20^{\circ} \mathrm{C}$ with an equal volume of isopropanol and $1 / 10$ volume of $7.5 \mathrm{M}$ ammonium acetate. The precipitate was washed twice with $75 \%$ ethanol, and then with 95\% ethanol. RNA was briefly air-dried and then resuspended and further purified using RNeasy columns (Qiagen; Valencia, CA). The amount and quality of RNA were determined by spectrophotometry and by electrophoresis through $1 \%$ agarose with ethidium bromide. RNA was further analyzed by the Agilent Bioanalyzer; samples that did not show two clear bands of ribosomal RNA were discarded.

\section{RNA Labeling, Hybridization and Scanning}

Preparation of cDNA, cRNA, and labeling were carried out according to the protocols recommended by Affymetrix in the GeneChip ${ }^{\circledast}$ Expression Analysis Technical Manual (Affymetrix, Santa Clara, CA), as previously described [2]. Hybridization was to Affymetrix GeneChip ${ }^{\circledast}$ Human Genome U133A microarrays, which measure approximately 22,000 genes. The microarrays were scanned using a dedicated Affymetrix Model 3000 7G scanner controlled by GCOS software.

\section{Statistical Analysis}

The average intensity on each array was normalized by global scaling to a target intensity of 1000 . Data were extracted using the Affymetrix Microarray Suite 5 (MAS5) algorithm. To avoid analyzing genes that were not reliably detected, the MAS5 data were filtered to eliminate any gene that was not called present in at least $50 \%$ of the samples in at least one group [27]. If a probeset was not reliably detected on day 1 but was later, it is noted as "turned on" and if it was detected on day 1 but not later it is noted as "turned off;" the exact fold change for such genes are not reliable because the signal for a gene that is 
not detected is largely background. Fold changes for each gene were calculated using the ratio of the MAS5 signals of the post treatment time to the baseline (pre-treatment). If the signal for the post-treatment time point was greater than the baseline the fold change was calculated as +average(post-treatment)/average(baseline), otherwise the fold change was calculated as -average(baseline)/average(posttreatment). Genes were considered significant if the paired t-test p-value of $\log ($ signal $) \leq 0.001$ and the fold change was at least 1.5 .

Gene expression as a function of time was analyzed using Edge http://www.genomine.org/edge/[28]; values are calculated on the log transform, but are plotted as percent of maximum signal values with gnuplot http://www.gnu plot.info/ to show wider range of values. The 90 genes most significant across all time points (by 1-way ANOVA) were clustered using Pearsons dissimilarity and average linkage, using Partek Genomics Suite (Partek Inc. St. Louis, MO); arrays were ordered by day to show the pattern of expression across time.

\section{Results}

Of the 20 patients enrolled, 19 were European American and one was African American. Sixteen were male. All were genotype 1,14 with genotype $1 \mathrm{~A}$ and 6 with genotype $1 \mathrm{~B}$. The baseline features of the 20 patients in this study are shown in Table 1 . In this cohort, $11 / 20$ had advanced hepatic fibrosis (Metavir stage 3-4), with 17/20 having high viral load $(>600,000 \mathrm{IU} / \mathrm{mL})$. The overall sustained viral response rate (SVR) at the end of treatment (72 weeks) was $35 \%$; i.e. $7 / 20$ individuals had undetectable virus at 72 weeks. Table 2 presents virus titers with time. By week 12 there were 11/20 patients who cleared virus, however one withdrew from treatment because of severe side effects, and 2 relapsed by the end of treatment.

\section{Changes in Global Gene Expression}

Gene expression in PBMC changed dramatically and rapidly during PEG-interferon- $\alpha 2 \mathrm{~b}$ (PegIntron ${ }^{\mathrm{TM}}$ )/ribavirin therapy, with major changes being evident at all days after the initial administration of the drugs (Table 3, Figure 1). There was no significant difference in response between patients with genotype $1 \mathrm{~A}$ and $1 \mathrm{~B}$, nor between responders and non-responders, so all patients were analyzed together. 973 genes were significantly $(\mathrm{p} \leq 0.001$; False Discovery Rate [29] 1.2\%) induced or down regulated on day 3; the number induced was approximately the same as the number down-regulated, as was seen in our earlier study [2]. The number of differentially expressed genes varied with time (Table 3, Figure 1); it was high on days 3 and 10 (mid-way between injections) and much lower on days 6,13 and 42 (just before subsequent injections) (Table 3, Figure 1). The number of genes with altered expression was high again, particularly for down regulated genes, at day 70. Half of the up-regulated genes but only $16 \%$ of the down-regulated genes showed at least 1.5 -fold change (Table 3). For our subsequent analyses we focused on the genes with more robust changes $(p=0.001$ and absolute fold-change $\geq 1.5$ ).

There were 69 genes that showed at least 1.5 -fold differences in expression at either 6 or all 7 time points: 59 upregulated and 10 down-regulated (Table 4 ). Many of these up regulated genes have previously been shown to be regulated by interferon $[2,25,26]$. A full list of all genes induced or down regulated at $\mathrm{p} \leq 0.001$ at any one day compared to day 1 is presented in Supplementary Table 1.

There is a strong pattern of gene expression as a function of time, as demonstrated by hierarchical clustering of the 90 genes that differed most (Figure 2). There is a clearly visible, alternating pattern of increases and decreases that decays over time. The patterns of gene expression can be divided into four groups. The top cluster are genes that are decreased as a result of treatment. These include genes associated with protein synthesis including eukaryotic initiation and elongation factors (EIF4B, EEI2, EIF3S5) and genes involved in ribosomal proteins (RPL3). The majority of genes fall into a second group, highly induced at days 3 and 10 but showing a decrease at day 6 and 13; the alternation decreases with time but is still high at day 70 . This includes most of the well characterized IFN inducible genes, including MX1, MX2, OAS1, OAS2, OAL, RIG1 (DDX58) and most interferon stimulated genes (ISGs). A third group are transiently induced genes, i.e. genes induced at day 3 and then returning to base line at later times (Table 5); many have been described as important in the interferon antiviral response and include CXCL10, IL1RA (IL1RN), JAK2, TNFSF10 (TRAIL), as well as CDKN1C, CXCL10, SMD4A. The last two genes at the bottom of the cluster array represent genes that are induced late. As is obvious for GYPA (glycophorin A), induction for such genes begins around day 27 and proceeds through day 70. Most of the genes in this latter group are related to blood chemistry, including hemoglobin complex formation, heme binding and oxygen transport (Table 6), which may reflect secondary response to long term treatment with ribavirin. A more complete list of genes in each category is presented in the accompanying Tables 4,5 and 6 .

To further examine the variation of gene expression with time, we used Edge software [28], which tests for changes in gene expression over time vs. the null hypothesis that the gene was expressed at a constant level. Among the 518 gene probes that were significantly modulated (absolute fold change $\geq 1.5, \mathrm{p} \leq 0.001$ ) at any one time point in the study (Supplementary Table 1) 90\% were shown to be differentially regulated over time ( $\mathrm{p} \leq 0.001$; False Discovery 
Table 2: Viral titer with time.

\begin{tabular}{|c|c|c|c|c|c|c|c|c|c|c|c|c|c|c|}
\hline $\begin{array}{l}\text { Patient } \\
\text { ID }\end{array}$ & $\begin{array}{c}\text { Day } 0 \\
\text { HCV } \\
\text { RNA } \\
\text { level } \\
\text { (IU/MI) }\end{array}$ & Day 3 & Day 7 & Day 10 & Day 13 & Day 27 & $\begin{array}{c}\text { Week } \\
6\end{array}$ & $\begin{array}{c}\text { Week } \\
10\end{array}$ & $\begin{array}{c}\text { Viral } \\
\text { Respon } \\
\text { se }^{*}\end{array}$ & $\begin{array}{l}\text { Week } \\
12\end{array}$ & $\begin{array}{c}\text { Week } \\
24\end{array}$ & $\begin{array}{c}\text { Week } \\
48\end{array}$ & $\begin{array}{l}\text { Week } \\
72\end{array}$ & $\begin{array}{l}\text { Final } \\
\text { Respon } \\
\text { se }\end{array}$ \\
\hline 1 & $\begin{array}{c}\text { I.7E+0 } \\
6\end{array}$ & $\begin{array}{c}3.5 \mathrm{E}+0 \\
5\end{array}$ & $\begin{array}{c}3.7 \mathrm{E}+0 \\
5\end{array}$ & $\begin{array}{c}\mathrm{I} .0 \mathrm{E}+0 \\
5\end{array}$ & $\begin{array}{c}2.3 \mathrm{E}+0 \\
5\end{array}$ & $\begin{array}{c}9.6 \mathrm{E}+0 \\
4\end{array}$ & $\begin{array}{c}8.3 \mathrm{E}+0 \\
4\end{array}$ & $\begin{array}{c}5.3 \mathrm{E}+0 \\
3\end{array}$ & $N R$ & $\begin{array}{c}2.0 \mathrm{E}+0 \\
3\end{array}$ & 0 & 0 & $N R$ & $N R$ \\
\hline 2 & $\begin{array}{c}7.0 \mathrm{E}+0 \\
5\end{array}$ & $\begin{array}{c}1.3 E+0 \\
5\end{array}$ & $\begin{array}{c}9.2 \mathrm{E}+0 \\
4\end{array}$ & $\begin{array}{c}1.5 E+0 \\
3\end{array}$ & $\begin{array}{c}3.8 \mathrm{E}+0 \\
3\end{array}$ & 0 & 0 & 0 & $\mathrm{R}$ & 0 & 0 & 0 & 0 & $\mathrm{R}$ \\
\hline 3 & $\begin{array}{c}3.4 \mathrm{E}+0 \\
6\end{array}$ & $\begin{array}{c}1.5 E+0 \\
6\end{array}$ & $\begin{array}{c}2.8 \mathrm{E}+0 \\
6\end{array}$ & $\begin{array}{c}\text { I.IE+0 } \\
6\end{array}$ & $\begin{array}{c}1.9 E+0 \\
6\end{array}$ & $\begin{array}{c}1.6 E+0 \\
6\end{array}$ & $\begin{array}{c}1.9 E+0 \\
6\end{array}$ & $\begin{array}{c}6.3 \mathrm{E}+0 \\
5\end{array}$ & NR & $\begin{array}{c}3.8 \mathrm{E}+0 \\
5\end{array}$ & & & $N R$ & NR \\
\hline 4 & $\begin{array}{c}\text { I.IE+0 } \\
7\end{array}$ & $\begin{array}{c}3.5 \mathrm{E}+0 \\
5\end{array}$ & $\begin{array}{c}\text { 6. IE+0 } \\
5\end{array}$ & $\begin{array}{c}3.6 \mathrm{E}+0 \\
4\end{array}$ & $\begin{array}{c}1.7 \mathrm{E}+0 \\
5\end{array}$ & $\begin{array}{c}9.0 \mathrm{E}+0 \\
3\end{array}$ & $\begin{array}{c}5.7 E+0 \\
2\end{array}$ & 0 & $\mathrm{R}$ & 0 & 0 & 0 & 0 & $R$ \\
\hline 5 & $\begin{array}{c}3.5 \mathrm{E}+0 \\
6\end{array}$ & $\begin{array}{c}2.9 \mathrm{E}+0 \\
6\end{array}$ & $\begin{array}{c}1.6 \mathrm{E}+0 \\
6\end{array}$ & $\begin{array}{c}4.9 \mathrm{E}+0 \\
5\end{array}$ & $\begin{array}{c}1.4 \mathrm{E}+0 \\
6\end{array}$ & $\begin{array}{c}6.9 \mathrm{E}+0 \\
5\end{array}$ & $\begin{array}{c}4.7 \mathrm{E}+0 \\
5\end{array}$ & $\begin{array}{c}2.0 \mathrm{E}+0 \\
5\end{array}$ & NR & $\begin{array}{c}1.7 E+0 \\
5\end{array}$ & & & $N R$ & NR \\
\hline 6 & $\begin{array}{c}\text { I.IE+0 } \\
7\end{array}$ & $\begin{array}{c}4.0 \mathrm{E}+0 \\
6\end{array}$ & $\begin{array}{c}5.6 \mathrm{E}+0 \\
6\end{array}$ & $\begin{array}{c}3.9 E+0 \\
6\end{array}$ & $\begin{array}{c}6.3 E+0 \\
6\end{array}$ & $\begin{array}{c}2.3 \mathrm{E}+0 \\
6\end{array}$ & $\begin{array}{c}1.0 \mathrm{E}+0 \\
6\end{array}$ & $\begin{array}{c}2.2 \mathrm{E}+0 \\
5\end{array}$ & NR & $\begin{array}{c}7.5 \mathrm{E}+0 \\
5\end{array}$ & & & NR & $N R$ \\
\hline 7 & $\begin{array}{c}5.8 E+0 \\
6\end{array}$ & $\begin{array}{c}1.3 \mathrm{E}+0 \\
5\end{array}$ & $\begin{array}{c}9.9 \mathrm{E}+0 \\
4\end{array}$ & $\begin{array}{c}\text { I. } 4 \mathrm{E}+0 \\
4\end{array}$ & $\begin{array}{c}7.3 \mathrm{E}+0 \\
4\end{array}$ & $\begin{array}{c}1.3 \mathrm{E}+0 \\
3\end{array}$ & $\begin{array}{c}1.5 \mathrm{E}+0 \\
2\end{array}$ & 0 & $R$ & 0 & 0 & 0 & 0 & $R$ \\
\hline 8 & $\begin{array}{c}\text { I.IE+0 } \\
7\end{array}$ & $\begin{array}{c}1.9 \mathrm{E}+0 \\
5\end{array}$ & $\begin{array}{c}5.8 \mathrm{E}+0 \\
5\end{array}$ & $\begin{array}{c}2.2 \mathrm{E}+0 \\
4\end{array}$ & $\begin{array}{c}\text { no } \\
\text { sample }\end{array}$ & $\begin{array}{c}2.6 \mathrm{E}+0 \\
3\end{array}$ & $\begin{array}{c}8.7 \mathrm{E}+0 \\
\mathrm{I}\end{array}$ & 0 & $\mathrm{R}$ & 0 & 0 & 0 & 0 & $\mathrm{R}$ \\
\hline 9 & $\begin{array}{c}7.2 \mathrm{E}+0 \\
6\end{array}$ & $\begin{array}{c}8.8 \mathrm{E}+0 \\
3\end{array}$ & $\begin{array}{c}2.2 \mathrm{E}+0 \\
5\end{array}$ & $\begin{array}{c}1.9 E+0 \\
3\end{array}$ & $\begin{array}{c}4.4 \mathrm{E}+0 \\
3\end{array}$ & 0 & 0 & 0 & $\mathrm{R}$ & 0 & 0 & 0 & 0 & $R$ \\
\hline 10 & $\begin{array}{c}2.3 \mathrm{E}+0 \\
6\end{array}$ & $\begin{array}{c}1.7 E+0 \\
6\end{array}$ & $\begin{array}{c}5.3 E+0 \\
6\end{array}$ & $\begin{array}{c}\text { 6. IE+0 } \\
5\end{array}$ & $\begin{array}{c}1.0 E+0 \\
6\end{array}$ & $\begin{array}{c}5.5 \mathrm{E}+0 \\
5\end{array}$ & $\begin{array}{c}3.6 \mathrm{E}+0 \\
5\end{array}$ & $\begin{array}{c}8.0 \mathrm{E}+0 \\
5\end{array}$ & NR & $\begin{array}{c}3.1 E+0 \\
5\end{array}$ & & & $N R$ & NR \\
\hline 11 & $\begin{array}{c}7.1 \mathrm{IE}+0 \\
6\end{array}$ & $\begin{array}{c}1.9 E+0 \\
6\end{array}$ & $\begin{array}{c}2.7 E+0 \\
6\end{array}$ & $\begin{array}{c}2.0 \mathrm{E}+0 \\
6\end{array}$ & $\begin{array}{c}5.8 \mathrm{E}+0 \\
6\end{array}$ & $\begin{array}{c}1.9 E+0 \\
6\end{array}$ & $\begin{array}{c}1.9 E+0 \\
6\end{array}$ & $\begin{array}{c}1.4 E+0 \\
6\end{array}$ & NR & $\begin{array}{c}6.7 E+0 \\
5\end{array}$ & & & NR & NR \\
\hline 12 & $\begin{array}{c}2.4 \mathrm{E}+0 \\
6\end{array}$ & $\begin{array}{c}1.7 E+0 \\
7\end{array}$ & $\begin{array}{c}3.3 \mathrm{E}+0 \\
6\end{array}$ & $\begin{array}{c}\text { I. } 3 E+0 \\
6\end{array}$ & $\begin{array}{c}2.0 \mathrm{E}+0 \\
6\end{array}$ & $\begin{array}{c}7.3 E+0 \\
5\end{array}$ & $\begin{array}{c}5.4 \mathrm{E}+0 \\
5\end{array}$ & $\begin{array}{c}1.0 \mathrm{E}+0 \\
5\end{array}$ & NR & $\begin{array}{c}6.6 \mathrm{E}+0 \\
4\end{array}$ & & & NR & $N R$ \\
\hline 13 & $\begin{array}{c}5.8 \mathrm{E}+0 \\
6\end{array}$ & $\begin{array}{c}9.9 \mathrm{E}+0 \\
5\end{array}$ & $\begin{array}{c}9.2 \mathrm{E}+0 \\
5\end{array}$ & $\begin{array}{c}\text { I.IE+0 } \\
5\end{array}$ & $\begin{array}{c}1.9 \mathrm{E}+0 \\
5\end{array}$ & $\begin{array}{c}\text { I. } 4 \mathrm{E}+0 \\
5\end{array}$ & $\begin{array}{c}7.4 \mathrm{E}+0 \\
3\end{array}$ & $\begin{array}{c}1.5 \mathrm{E}+0 \\
2\end{array}$ & $\mathrm{R}$ & 0 & 0 & 0 & 0 & $\mathrm{R}$ \\
\hline 14 & $\begin{array}{c}3.7 \mathrm{E}+0 \\
5\end{array}$ & $\begin{array}{c}1.0 \mathrm{E}+0 \\
5\end{array}$ & $\begin{array}{c}2.3 \mathrm{E}+0 \\
5\end{array}$ & $\begin{array}{c}7.0 \mathrm{E}+0 \\
4\end{array}$ & $\begin{array}{c}1.2 \mathrm{E}+0 \\
5\end{array}$ & $\begin{array}{c}7.0 \mathrm{E}+0 \\
3\end{array}$ & $\begin{array}{c}3.9 \mathrm{E}+0 \\
2\end{array}$ & $\begin{array}{c}1.6 \mathrm{E}+0 \\
2\end{array}$ & $\mathrm{R}$ & 0 & 0 & 0 & $\begin{array}{c}1.2 \mathrm{E}+0 \\
6\end{array}$ & $N R$ \\
\hline 15 & $\begin{array}{c}1.8 \mathrm{E}+0 \\
6\end{array}$ & $\begin{array}{c}3.8 \mathrm{E}+0 \\
5\end{array}$ & $\begin{array}{c}1.0 \mathrm{E}+0 \\
6\end{array}$ & $\begin{array}{c}4.2 E+0 \\
5\end{array}$ & $\begin{array}{c}8.0 \mathrm{E}+0 \\
5\end{array}$ & $\begin{array}{c}1.9 E+0 \\
5\end{array}$ & $\begin{array}{c}2.3 \mathrm{E}+0 \\
4\end{array}$ & $\begin{array}{c}2.0 \mathrm{E}+0 \\
3\end{array}$ & $\mathrm{R}$ & $\begin{array}{c}3.6 \mathrm{E}+0 \\
3\end{array}$ & & & NR & NR \\
\hline 16 & $\begin{array}{c}1.6 \mathrm{E}+0 \\
6\end{array}$ & $\begin{array}{c}\text { 2. } I E+0 \\
6\end{array}$ & $\begin{array}{c}3.9 E+0 \\
6\end{array}$ & $\begin{array}{c}8.0 \mathrm{E}+0 \\
5\end{array}$ & $\begin{array}{c}5.8 \mathrm{E}+0 \\
6\end{array}$ & $\begin{array}{c}5.4 \mathrm{E}+0 \\
6\end{array}$ & $\begin{array}{c}\text { 2. IE+0 } \\
6\end{array}$ & $\begin{array}{c}1.3 E+0 \\
6\end{array}$ & NR & $\begin{array}{c}7.7 E+0 \\
4\end{array}$ & & & NR & NR \\
\hline 17 & $\begin{array}{c}\text { 4. IE+0 } \\
5\end{array}$ & $\begin{array}{c}1.2 \mathrm{E}+0 \\
5\end{array}$ & $\begin{array}{c}1.2 \mathrm{E}+0 \\
6\end{array}$ & $\begin{array}{c}\text { I. } 3 E+0 \\
5\end{array}$ & $\begin{array}{c}6.1 E+0 \\
5\end{array}$ & $\begin{array}{c}3 . I E+0 \\
4\end{array}$ & $\begin{array}{c}7.5 E+0 \\
3\end{array}$ & $\begin{array}{c}4.5 \mathrm{E}+0 \\
\mathrm{I}\end{array}$ & $\mathrm{R}$ & 0 & 0 & 0 & 0 & $R$ \\
\hline 18 & $\begin{array}{c}9.0 \mathrm{E}+0 \\
5\end{array}$ & $\begin{array}{c}1.5 \mathrm{E}+0 \\
6\end{array}$ & $\begin{array}{c}6.2 \mathrm{E}+0 \\
6\end{array}$ & $\begin{array}{c}4.3 \mathrm{E}+0 \\
5\end{array}$ & $\begin{array}{c}1.4 \mathrm{E}+0 \\
6\end{array}$ & $\begin{array}{c}3.2 \mathrm{E}+0 \\
5\end{array}$ & $\begin{array}{c}3.3 \mathrm{E}+0 \\
5\end{array}$ & $\begin{array}{c}2.5 \mathrm{E}+0 \\
5\end{array}$ & NR & $\begin{array}{c}4.8 \mathrm{E}+0 \\
4\end{array}$ & & & NR & $N R$ \\
\hline 19 & $\begin{array}{c}4.0 \mathrm{E}+0 \\
5\end{array}$ & $\begin{array}{c}8.7 E+0 \\
4\end{array}$ & $\begin{array}{c}6.9 \mathrm{E}+0 \\
5\end{array}$ & $\begin{array}{c}3 . I E+0 \\
4\end{array}$ & $\begin{array}{c}3.7 E+0 \\
4\end{array}$ & $\begin{array}{c}1.5 \mathrm{E}+0 \\
3\end{array}$ & $\begin{array}{c}1.0 \mathrm{E}+0 \\
3\end{array}$ & 0 & $\mathrm{R}$ & 0 & 0 & 0 & $\begin{array}{c}6.3 E+0 \\
6\end{array}$ & $N R$ \\
\hline 20 & $\begin{array}{c}8.1 E+0 \\
5\end{array}$ & $\begin{array}{c}3.3 E+0 \\
3\end{array}$ & $\begin{array}{c}1.9 \mathrm{E}+0 \\
3\end{array}$ & $\begin{array}{c}3.8 \mathrm{E}+0 \\
\mathrm{I}\end{array}$ & $\begin{array}{c}2.7 E+0 \\
2\end{array}$ & 0 & 0 & 0 & $R$ & 0 & W & W & $w$ & $\begin{array}{c}\text { withdr } \\
\text { ew }\end{array}$ \\
\hline
\end{tabular}

$* \mathrm{R}=$ responder, $\mathrm{NR}=$ non-responder .

$\mathrm{W}=$ withdrew

Rate $\leq 0.001$ ) in a cyclic fashion. The ten most differentially expressed of these genes are plotted in Figure 3. These same genes were previously selected by an unbiased mathematical model as being involved in interferon antiHCV activity [26].

\section{Comparison with previous studies}

To compare the level of induction or down regulation between this study and a previous study (Virahep C; [2]) performed with Peg-intron, we chose twenty patients from the Virahep C study for whom we had data from day 3 (note that day 3 in Virahep $\mathrm{C}$ was the fourth day after interferon injection, which was day 0 in that study). The top 20 genes in terms of fold change are shown in Table 7. All genes induced in both trials are presented in Supplementary Table 2 . Note that in the Virahep $\mathrm{C}$ study the dose of Peginterferon-alfa2a (Pegasys ${ }^{\mathrm{TM}}$ ) was $180 \mathrm{ug}$; in the present study the dose of Pegylated-interferon-alfa2b (PegIntron $^{\mathrm{TM}}$ ) was lower: $1.5 \mathrm{ug} / \mathrm{kg}$, for an average of 133 ug (standard deviation 25.6, maximum 174).

\section{Discussion}

The aim of this study was to examine the effects of Peg interferon alfa-2b (PegIntron ${ }^{\mathrm{TM}}$, administered at $1.5 \mathrm{ug} / \mathrm{kg}$ ) 
Table 3: Number of probe sets that significantly differed in expression $(p \leq 0.001)$.

\begin{tabular}{|c|c|c|c|c|c|c|c|c|}
\hline Fold Change & Expected* & Day 3 & Day 6 & Day 10 & Day 13 & Day 27 & Day 42 & Day 70 \\
\hline$N A^{* *}$ & 11 & 973 & 478 & 725 & 471 & 716 & 452 & 920 \\
\hline$\geq 1.5$ & $-\dagger$ & 290 & 165 & 255 & 142 & 194 & 157 & 289 \\
\hline$\% \geq 1.5$ & & $30 \%$ & $35 \%$ & $35 \%$ & $30 \%$ & $27 \%$ & $35 \%$ & $31 \%$ \\
\hline \multicolumn{9}{|l|}{ Up regulated } \\
\hline Fold Change & Expected* & Day 3 & Day 6 & Day 10 & Day 13 & Day 27 & Day 42 & Day 70 \\
\hline$N A^{* *}$ & $-\dagger$ & 472 & 237 & 344 & 229 & 340 & 234 & 406 \\
\hline$\geq 1.5$ & $-\dagger$ & 235 & 96 & 294 & 102 & 129 & 103 & 206 \\
\hline$\% \geq 1.5$ & & $50 \%$ & $41 \%$ & $85 \%$ & $45 \%$ & $38 \%$ & $44 \%$ & $51 \%$ \\
\hline \multicolumn{9}{|c|}{ Down regulated } \\
\hline Fold Change & Expected* & Day 3 & Day 6 & Day 10 & Day 13 & Day 27 & Day 42 & Day 70 \\
\hline NA** & $-\dagger$ & 501 & 241 & 381 & 242 & 376 & 218 & 514 \\
\hline$\leq-1.5$ & $-\dagger$ & 55 & 32 & 61 & 40 & 65 & 54 & 83 \\
\hline$\% \geq 1.5$ & & $11 \%$ & $13 \%$ & $16 \%$ & $17 \%$ & $17 \%$ & $25 \%$ & $16 \%$ \\
\hline
\end{tabular}

* Expected for normal distribution

** Not applicable; No fold change cutoff applied

† Not applicable

plus ribavirin on gene expression as a function of time in a cohort of patients infected with HCV genotype 1. The number of genes modified and the signal values for each individual gene induced or down regulated as a result of interferon treatment are remarkably similar between this study and others $[2,30,31]$. Virtually all genes identified as being important in the interferon response were induced approximately equally in this study and the Virahep $\mathrm{C}$ clinical trial $[2,23]$, despite the different interferon used (PegIntron $^{\mathrm{TM}}$ here $v$ s. Pegasys ${ }^{\mathrm{TM}}$ in Virahep C) and the difference in dose (Table 7 and Supplementary Table 2). The few apparent differences were on the borderline of being significant or close to the 1.5 fold cutoff we chose. The kinetics of gene induction was also very similar, with most genes being induced early and elevated throughout the trial period. This was true despite several differences between the studies. Virahep C study used peg interferon $\alpha-2 \mathrm{a}\left(\right.$ Pegasys $\left.^{\mathrm{TM}}\right)$, whereas here we used peg interferon $\alpha$ $2 \mathrm{~b}\left(\right.$ PegIntron $\left.^{\mathrm{TM}}\right)$. Another difference was the dose of interferon used; the Virahep C study used a constant amount (180 $\mu \mathrm{g} /$ injection), whereas here we adjusted dose based upon the initial weight of the patient $(1.5 \mu \mathrm{g} / \mathrm{kg})$. A third difference was that subjects for the Virahep C gene expression study were selected based on their viral titer response during the first 28 days of treatment, to allow comparison among fast responders, slow responders and nonresponders. In the present study, patients were not selected for response, but rather all subjects were analyzed, and only 3 subjects in the current study would have met the Virahep C criteria of rapid responders; this greatly reduced our power to detect differences in gene expression related to response. Considering that these trials were done a few years apart, and with different populations, there was excellent agreement in the changes in gene expression. Some of the small differences seen are due to heterogeneity within the populations, and are apparent even at day 1, before initiation of treatment. For instance, the mean weight of this 20 person cohort was $88.4 \mathrm{~kg}$ which correlates with the those in the Virahep $\mathrm{C}$ cohort having intermediate or poor response, and 11/20 individuals had bridging fibrosis or cirrhosis. In addition, there was just one African American in this cohort.

As can be seen from Figure 1 and Table 3, and Supplementary table 1 a large number of genes are initially induced following treatment. In the earlier study, the peak was at day 1 after treatment [2], however this time point was not included in the present study; thus in the present study the peak was observed at the earliest time point after injection, day 3. In general, there was very good agreement in the fold increase in gene expression at day 3 (Table 7 and Supplementary Table 2). As in the case of Virahep C, there is a decline in both the number of genes induced and the extent of gene elevation before the next injection of interferon, at day 6 here and day 7 in the Virahep C study. At that time there is a small increase in viral titer. This pattern appears to be repeated until about a month into the study (Table 3, Figures 1, 2 and 3), which might suggest that interferon treatment more frequently than once a week would be more efficacious in early stages of treatment.

Among the major functional categories of genes induced at day 3 (based on Gene Ontology categories and KEGG pathways) are innate immune response, transcription factors, and chemotaxis. Many of these genes have previously been reported to be induced primarily by IFN-gamma, suggesting low amounts of IFN-gamma may be induced, although we could not detect IFN-gamma in our arrays. 


\section{Gene probes modified with time}

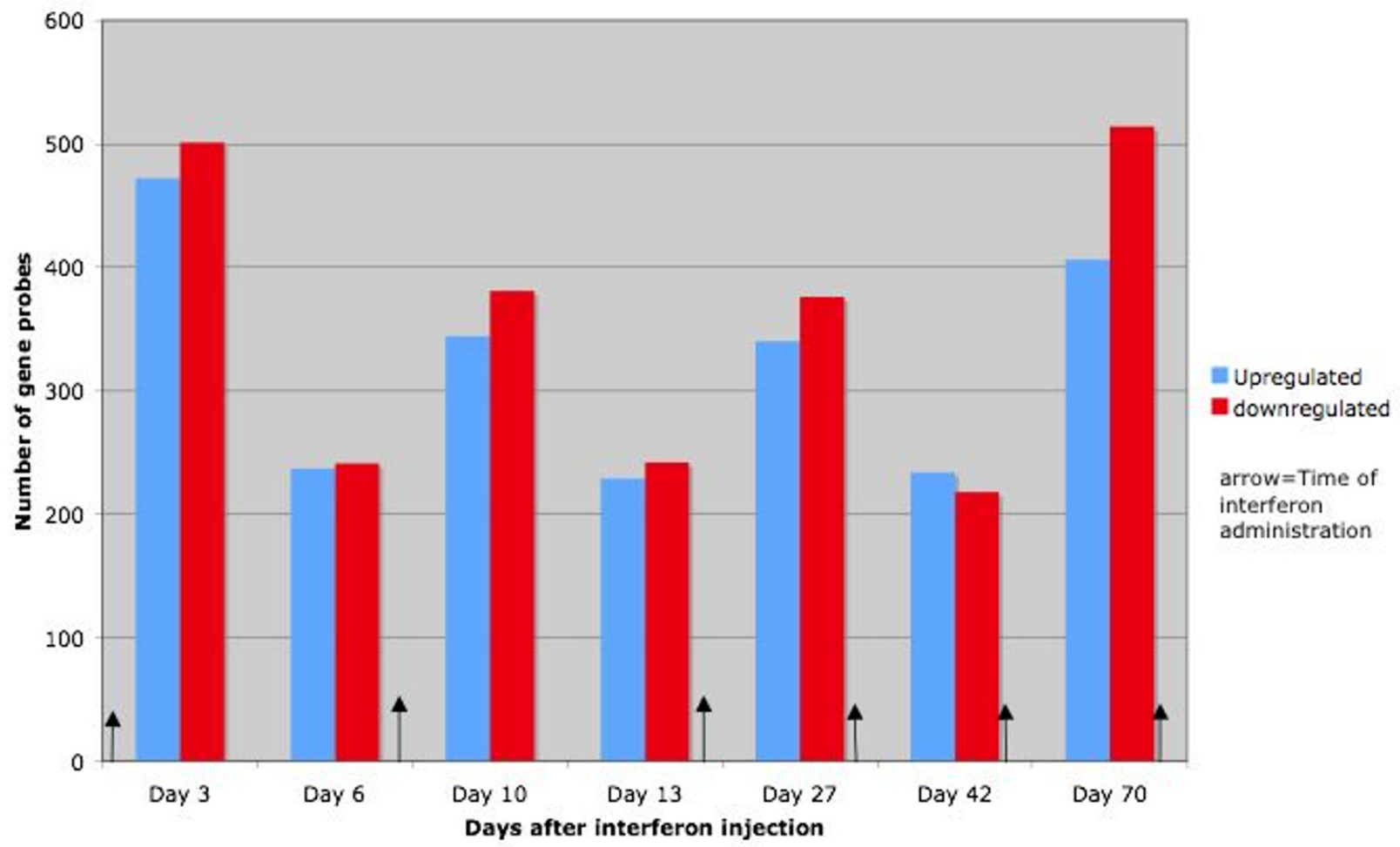

Figure I

The number of genes significantly upregulated or down-regulated $(p \leq 0.00 \mathrm{I})$ at each time point.

We have divided the gene responses into four categories: genes that are induced early and once induced are induced throughout the trial period, genes transiently induced, those that appear late and down regulated genes (Tables $4,5,6)$. Most of these genes fall into a similar temporal category in the previous study [2]. Most of the genes that are induced (or down regulated) throughout the studied period (up to 10 weeks; Table 4 and Supplementary Table 1) were previously identified as being involved in the interferon response [2,22-25,32]. Among gene functions significantly altered by IFN are genes involved in the immune response including inflammation, genes previously reported to be involved in response to virus infection and transcription factors (DNA and RNA binding proteins).

Among the genes transiently expressed is CXCL10. It has been proposed previously that the levels of this gene are related to the final outcome of treatment $[33,34]$. However both in this trial and in the Virahep $\mathrm{C}$ trial, this gene is only expressed at enhanced levels for the first few days after initiation of IFN treatment, and by day 13 is back to baseline levels. We have not found a correlation between CXCL10 expression and response to treatment. Protein levels (ELISA data not shown) follow the mRNA levels. IL1ra $(I L 1 R N)$ has previously been reported to be transiently expressed at the protein level following interferon treatment [35], and, as can be seen from Table 5, this is confirmed in the microarray data.

TNFSF10 (tumor necrosis factor (ligand) superfamily, member 10, TRAIL), a gene associated with apoptosis in transformed and tumor cells [36] and recently shown to have direct anti-viral activity against dengue virus [37], is induced early but only transiently. This gene was shown to be induced at high levels during the early stages of treat- 
Table 4: Genes differentially expressed ( 1.5 -fold) at $\geq 6$ time points

\begin{tabular}{|c|c|c|c|c|c|c|c|c|}
\hline Symbol & Day 3 & Day 6 & Day 10 & Day 13 & Day 27 & Day 42 & Day 70 & Description \\
\hline \multicolumn{9}{|l|}{ Up regulated } \\
\hline Gene name & & & & & & & & Other name/function \\
\hline AGRN & 2.1 & 1.7 & 2.1 & 1.9 & 1.6 & 1.7 & 2.1 & agrin \\
\hline АРОВЕСЗА & 2.9 & 2.0 & 2.7 & 1.9 & 1.9 & 1.8 & 2.0 & $\begin{array}{l}\text { apolipoprotein B mRNA editing enzyme, catalytic } \\
\text { polypeptide-like } 3 A\end{array}$ \\
\hline CHMP5 & 2.8 & 1.9 & 2.6 & 2.0 & 1.9 & 1.8 & 1.9 & chromatin modifying protein 5 \\
\hline DDX58 & 2.8 & 1.8 & 2.6 & 1.7 & 1.8 & 1.6 & 1.7 & RNA helicase RIG-I \\
\hline EIF2AK2 & 2.6 & 1.9 & 2.6 & 2.2 & 2.0 & 2.0 & 2.4 & Eukaryotic translation initiation factor 2-alpha kinase 2 \\
\hline FLJII 286 & 1.8 & 1.5 & 1.8 & 1.6 & 1.5 & 1.6 & 1.6 & Cl9orf66 \\
\hline FLJ20035 & 3.8 & 3.0 & 3.6 & 2.7 & 2.5 & 2.6 & 2.7 & $\mathrm{DD} \times 60$ \\
\hline HIFO & 3.1 & 1.6 & 2.1 & 1.8 & 1.9 & 2.1 & 2.5 & $\mathrm{HI}$ histone family, member 0 \\
\hline HERC5 & 4.5 & 2.1 & 4.1 & 2.5 & 2.6 & 2.5 & 2.7 & Ubiquitin ligase/mediates ISGylation of protein targets \\
\hline HERC6 & 5.9 & 4.1 & 5.7 & 4.1 & 4.1 & 4.2 & 4.2 & Ubiquitin ligase \\
\hline HISTIHIC & 2.6 & 1.6 & 2.4 & 1.7 & 2.6 & 2.4 & 3.2 & histone cluster I, $\mathrm{HIC}$ \\
\hline HISTIH2AE & 2.4 & 2.0 & 3.3 & 2.1 & 2.5 & 2.6 & 3.8 & histone cluster $\mathrm{I}, \mathrm{H} 2 \mathrm{ae}$ \\
\hline HISTIH2BC & 2.5 & 2.0 & 2.7 & 1.9 & 2.0 & 2.2 & 2.8 & histone cluster $\mathrm{I}, \mathrm{H} 2 \mathrm{bg} / / /$ histone cluster $\mathrm{I}, \mathrm{H} 2 \mathrm{bc}$ \\
\hline HISTIH2BD & 2.1 & 1.7 & 2.3 & 1.6 & 1.7 & 1.6 & 2.2 & histone cluster $\mathrm{I}, \mathrm{H} 2 \mathrm{bd}$ \\
\hline HISTIH2BF & 2.4 & 1.9 & 2.5 & 1.8 & 1.9 & 1.5 & 2.2 & histone cluster $\mathrm{I}, \mathrm{H} 2 \mathrm{bf}$ \\
\hline HISTIH2BG & 4.3 & 2.8 & 3.6 & 3.5 & 3.3 & 2.4 & 3.4 & histone cluster $\mathrm{I}, \mathrm{H} 2 \mathrm{bg}$ \\
\hline HISTIH2BI & 2.4 & 1.9 & 2.5 & 1.9 & 2.0 & 1.5 & 2.2 & histone cluster $\mathrm{I}, \mathrm{H} 2 \mathrm{bi}$ \\
\hline HIST2H2AA3 & 3.1 & 1.8 & 2.8 & 1.8 & 2.1 & 2.1 & 2.8 & histone cluster $2, \mathrm{H} 2 \mathrm{aa} 3 / / /$ histone cluster $2, \mathrm{H} 2 \mathrm{aa} 4$ \\
\hline $\mathrm{IFI} 27$ & 73.3 & 70.3 & 98.0 & 93.5 & 94.8 & 97.4 & 107.7 & interferon, alpha-inducible protein 27 (ISG I2, P27) \\
\hline IFI35 & 3.2 & 2.0 & 2.9 & 2.0 & 1.8 & 1.9 & 1.9 & interferon-induced protein 35 \\
\hline IFI44 & 7.1 & 4.8 & 6.5 & 4.8 & 4.5 & 5.2 & 5.0 & Interferon-induced protein 44, p44 \\
\hline IFI44L & 10.1 & 8.2 & 9.7 & 7.6 & 7.5 & 8.0 & 8.4 & interferon-induced protein 44 -like \\
\hline IFIHI & 3.3 & 2.0 & 3.3 & 2.4 & 2.1 & 2.3 & 2.2 & interferon induced with helicase $C$ domain I \\
\hline IFITI & 12.2 & 4.1 & 9.9 & 6.0 & 4.8 & 5.6 & 4.8 & $\begin{array}{l}\text { interferon-induced protein with tetratricopeptide } \\
\text { repeats I }\end{array}$ \\
\hline IFIT3 & 7.1 & 3.3 & 6.8 & 3.8 & 3.4 & 3.5 & 3.9 & $\begin{array}{l}\text { interferon-induced protein with tetratricopeptide } \\
\text { repeats } 3\end{array}$ \\
\hline IFIT5 & 2.7 & 1.9 & 2.7 & 2.4 & 2.0 & 2.2 & 1.8 & $\begin{array}{l}\text { interferon-induced protein with tetratricopeptide } \\
\text { repeats } 5\end{array}$ \\
\hline IFITMI & 2.0 & 1.6 & 1.9 & 1.7 & 1.7 & 1.7 & 1.7 & interferon induced transmembrane protein I (9-27) \\
\hline IFITM3 & 2.2 & 1.8 & 2.1 & 1.8 & 1.7 & 1.8 & 2.0 & interferon induced transmembrane protein $3(\mathrm{I}-8 \mathrm{U})$ \\
\hline IRF7 & 3.7 & 2.4 & 3.3 & 2.5 & 2.2 & 2.5 & 2.4 & interferon regulatory factor 7 \\
\hline ISG I5 & 6.8 & 3.8 & 6.6 & 4.0 & 3.9 & 4.4 & 4.2 & ISG I 5 ubiquitin-like modifier \\
\hline ISG20 & 2.5 & 1.8 & 2.6 & 1.8 & 1.7 & 1.6 & 1.7 & interferon stimulated exonuclease gene $20 \mathrm{kDa}$ \\
\hline LAMP3 & 6.0 & 3.1 & 6.7 & 3.3 & 3.8 & 3.9 & 4.4 & lysosomal-associated membrane protein 3 \\
\hline LGALS3BP & 4.0 & 2.2 & 4.0 & 2.8 & 2.6 & 3.0 & 3.1 & lectin, galactoside-binding, soluble, 3 binding protein \\
\hline LOC26010 & 4.3 & 2.5 & 4.2 & 3.0 & 3.0 & 3.1 & 3.3 & viral DNA polymerase-transactivated protein 6 \\
\hline LOC391020 & 2.7 & 2.0 & 2.7 & 2.2 & 2.1 & 2.2 & 2.5 & interferon induced transmembrane protein pseudogene \\
\hline LY6E & 4.1 & 2.7 & 4.0 & 3.1 & 2.8 & 3.0 & 3.4 & lymphocyte antigen 6 complex, locus $E$ \\
\hline MXI & 5.0 & 3.5 & 4.9 & 3.8 & 3.7 & 3.9 & 4.1 & $\begin{array}{l}\text { myxovirus (influenza virus) resistance I, interferon- } \\
\text { inducible protein p78 (mouse) }\end{array}$ \\
\hline$M \times 2$ & 3.1 & 2.1 & 2.9 & 2.2 & 2.2 & 2.3 & 2.4 & myxovirus (influenza virus) resistance 2 (mouse) \\
\hline N4BPI & 1.5 & 1.5 & 1.7 & 1.6 & 1.6 & 1.7 & 1.6 & Nedd4 binding protein I \\
\hline OASI & 4.3 & 2.4 & 3.8 & 2.5 & 2.1 & 2.3 & 2.3 & 2 ',5'-oligoadenylate synthetase $1,40 / 46 \mathrm{kDa}$ \\
\hline OAS2 & 3.5 & 2.4 & 3.4 & 2.9 & 2.4 & 2.5 & 2.5 & $2 '-5$ '-oligoadenylate synthetase $2,69 / 7 \mathrm{lkDa}$ \\
\hline OAS3 & 4.5 & 2.6 & 3.8 & 2.7 & 2.3 & 2.5 & 2.8 & 2'-5'-oligoadenylate synthetase $3,100 \mathrm{kDa}$ \\
\hline OASL & 4.6 & 2.1 & 4.1 & 2.7 & 2.2 & 2.5 & 2.6 & 2'-5'-oligoadenylate synthetase-like \\
\hline PARPI2 & 2.4 & 1.8 & 2.3 & 1.8 & 1.8 & 1.9 & 1.9 & poly (ADP-ribose) polymerase family, member 12 \\
\hline PHFII & 1.8 & 1.6 & 1.8 & 1.6 & 1.7 & 1.7 & 1.7 & PHD finger protein II \\
\hline PLSCRI & 3.1 & 1.9 & 2.8 & 2.1 & 2.1 & 2.1 & 2.4 & phospholipid scramblase I \\
\hline RNASE2 & 2.9 & 1.9 & 2.3 & 1.8 & 1.7 & 1.7 & 1.9 & $\begin{array}{l}\text { ribonuclease, RNase A family, } 2 \\
\text { (liver, eosinophil-derived neurotoxin) }\end{array}$ \\
\hline RSAD2 & 12.8 & 5.3 & 11.6 & 6.8 & 6.4 & 6.4 & 6.6 & radical S-adenosyl methionine domain containing 2 \\
\hline SAMD 9 & 3.8 & 2.1 & 3.3 & 2.6 & 2.1 & 2.1 & 2.0 & sterile alpha motif domain containing 9 \\
\hline SERPINGI & 4.9 & 1.9 & 4.1 & 2.3 & 1.9 & 2.0 & 2.1 & $\begin{array}{l}\text { serpin peptidase inhibitor, clade } \mathrm{G}(\mathrm{Cl} \text { inhibitor), } \\
\text { member I, (angioedema, hereditary) }\end{array}$ \\
\hline SIGLECI & 27.1 & 16.5 & 23.1 & 17.0 & 13.7 & 18.2 & 20.9 & sialic acid binding Ig-like lectin I, sialoadhesin \\
\hline
\end{tabular}


Table 4: Genes differentially expressed ( 1.5 -fold) at $\geq 6$ time points (Continued)

\begin{tabular}{|c|c|c|c|c|c|c|c|c|}
\hline SPI00 & 1.9 & 1.7 & 1.9 & 1.6 & 1.6 & 1.5 & 1.8 & SPI00 nuclear antigen \\
\hline SPIIO & 1.9 & 1.5 & 1.9 & 1.5 & 1.5 & 1.5 & 1.6 & SPIIO nuclear body protein \\
\hline USPI8 & 7.4 & 4.9 & 7.5 & 5.1 & 4.5 & 5.3 & 5.5 & ubiquitin specific peptidase 18 \\
\hline XAFI & 4.3 & 3.3 & 3.8 & 2.9 & 2.9 & 2.5 & 3.1 & XIAP associated factor-I \\
\hline ZBPI & 3.0 & 2.2 & 3.0 & 2.2 & 2.1 & 2.2 & 2.2 & Z-DNA binding protein I \\
\hline $\mathrm{ZCCHC2}$ & 2.3 & 1.9 & 2.2 & 1.7 & 1.8 & 1.8 & 1.8 & zinc finger, $\mathrm{CCHC}$ domain containing 2 \\
\hline cDNA CSODK002YFI3 & 3.3 & 2.6 & 3.4 & 2.6 & 2.5 & 2.7 & 2.8 & $\begin{array}{l}\text { Full-length cDNA clone CSODK002YFI } 3 \text { of HeLa cells } \\
\text { Cot } 25 \text {-normalized of Homo sapiens (human) }\end{array}$ \\
\hline cDNA FLJII754 & 3.1 & 2.4 & 3.1 & 2.3 & 2.6 & 2.6 & 2.6 & CDNA FLJII 754 fis, clone HEMBAI005588 \\
\hline \multicolumn{9}{|l|}{ Down regulated } \\
\hline ALDHIAI & -1.5 & -1.7 & -1.7 & -2.0 & -2.5 & -2.5 & -2.6 & aldehyde dehydrogenase I family, member AI \\
\hline CDKNIC & 1.9 & -2.1 & -1.1 & -1.7 & -1.7 & -1.7 & -1.7 & cyclin-dependent kinase inhibitor IC (p57, Kip2) \\
\hline EIF3EIP & -2.0 & -1.6 & -2.0 & -1.8 & -1.6 & -1.6 & -1.7 & $\begin{array}{l}\text { eukaryotic translation initiation factor } 3 \text {, subunit } \mathrm{E} \\
\text { interacting protein }\end{array}$ \\
\hline EIF4B & -2.0 & -1.5 & -2.0 & -1.6 & -1.5 & -1.9 & -1.8 & eukaryotic translation initiation factor 4B \\
\hline FCERIA & -1.5 & -1.7 & -2.1 & -2.2 & -2.4 & -3.0 & -2.8 & $\begin{array}{l}\text { Fc fragment of IgE, high affinity I, receptor for; alpha } \\
\text { polypeptide }\end{array}$ \\
\hline INSR & -1.5 & -1.6 & -1.6 & -1.9 & -2.0 & -2.0 & -1.6 & insulin receptor \\
\hline LTA4H & -1.7 & -1.7 & -2.0 & -1.7 & -1.6 & -1.6 & -1.6 & leukotriene A4 hydrolase \\
\hline PAPSS2 & -1.7 & -1.7 & -1.8 & -1.6 & -1.6 & -1.3 & -1.6 & 3'-phosphoadenosine 5'-phosphosulfate synthase 2 \\
\hline PIDI & -2.0 & -1.8 & -2.3 & -1.8 & -1.8 & -1.9 & -1.9 & phosphotyrosine interaction domain containing I \\
\hline RTNI & -2.2 & -1.9 & -2.3 & -2.0 & -2.0 & -2.0 & -2.3 & reticulon I \\
\hline
\end{tabular}

Values in italics are not significant.

ment in our previous study [2]. It is possible that it has direct anti-hepatitis C activity. TNFAIP6 (TSG6) is also induced early; its gene product has been show to have anti-inflammatory activity and may inhibit TNF activity by a feed back loop [38,39].

AIM2 has been identified as part of a cluster of homologous genes (MNDA, IFI16 and AIM2) on human chromosome 1 [40] referred to as IFI or HIN-200 genes. It has been suggested that AIM2 functions as a tumor suppressor gene [41], however, over expression of AIM2 in another study did not induce a tumor suppressor phenotype [42]. AIM2 has homology to IFI16. However, whereas IFI16 is induced and highly expressed throughout the treatment period, AIM2 is not, indicating that the regulation of this gene differs from that of other HIN-200 family members.

TLR1 and FLN29 (TRAFD1), regulators of toll like receptor signaling [43], are both transiently induced. TLR1 is involved in recognition of viral antigens, and is found on the surface of most immune cells. On the other hand, TLR7 is induced through out the 10 week period.

CDKN1C (cyclin dependent kinase inhibitor 1C, alias p57, Kip2) behaves differently from all the other genes. The mRNA for this gene is elevated early, both in this trial and in the Virahep $\mathrm{C}$ trial, but is severely repressed at later times rather than returning to base line. This gene product is an inhibitor of several G1 cyclin/CdK complexes and a negative regulator of cell proliferation. CDKN1C plays a role in cell proliferation, differentiation, apoptosis, tumorgenesis and developmental changes. It has been reported that the $C D K N 1 C$ protein physically interacts with and inhibits the c-Jun NH2-terminal kinase/stress activated protein kinase (JNK/SAPK) [44]. It has also been reported to bind to the proliferating cell nuclear antigen (PCNA), and thus control the cell cycle [45]. This is the first report that this gene is regulated by interferon or ribavirin. Its role in the interferon/ribavirin response is unknown.

\section{Late Gene Induction}

One area very rarely studied is the change in profile of gene induction after a few weeks of treatment with IFN and ribavirin. Most of the late genes probably represent secondary or tertiary events, and include genes involved in hemopoiesis, hemoglobin complex formation, and oxygen transport and binding. Genes for the synthesis of hemoglobin delta and gamma are enhanced. There is no enhanced synthesis of $H B A$ or $H B B$, both of which are expressed at high levels. Carbonic anhydrase, which has been associated previously with erythrocytes [46], is also highly induced late in treatment. We noted that this gene was also induced late in patients in the Virahep $\mathrm{C}$ study. Its importance in blood chemistry or response to interferon is unknown. Glycophorins A (GYPA) and B (GYPB) are major sialoglycoproteins of the human erythrocyte membrane which bear the antigenic determinants for the $\mathrm{MN}$ and Ss blood groups [47]. The enhanced synthesis of these genes also indicates changes in the synthesis of erythrocytes. These changes may reflect the side effects of interferon or more likely ribavirin therapy. The major clinical side effect of ribavirin is a hemolytic anemia $[48,49]$, and thus the changes in expression of these genes may represent compensatory responses. 
Table 5: Transiently induced genes

\begin{tabular}{|c|c|c|}
\hline Symbol & Fold Change & Description \\
\hline ABCAI & 1.8 & ATP-binding cassette, sub-family $A(A B C I)$, member I \\
\hline $\mathrm{ABCC} 3$ & 1.7 & ATP-binding cassette, sub-family C (CFTR/MRP), member 3 \\
\hline AIM2 & 1.6 & Related to IFII6 \\
\hline ARRBI & 1.7 & arrestin, beta I \\
\hline CIQA & 1.6 & complement component I, q subcomponent, A chain \\
\hline CIQB & 2.0 & complement component I, q subcomponent, B chain \\
\hline CALML4 & 1.8 & calmodulin-like 4 \\
\hline CDKNIC & 2.2 & cyclin-dependent kinase inhibitor IC (p57, Kip2) \\
\hline CMKLRI & 2.0 & chemokine-like receptor I, chimerin \\
\hline CTSLI & 2.4 & cathepsin LI (lysosomal cysteine proteinase) \\
\hline CUTLI & 1.5 & cut-like I, CCAAT displacement protein (Drosophila) \\
\hline CXCLIO & 4.0 & chemokine (C-X-C motif) ligand 10 \\
\hline FAM46A & 1.6 & family with sequence similarity 46 , member $A$ \\
\hline FFAR2 (GPR43) & 2.7 & free fatty acid receptor 2 . \\
\hline hCG_1776259 & 1.9 & hypothetical protein FLJ23556 (unknown function) \\
\hline ILIRN̄ & 2.1 & interleukin I receptor antagonist \\
\hline JAK2 & 1.7 & Janus kinase 2 (a protein tyrosine kinase) \\
\hline LILRA3 & 1.6 & leukocyte immunoglobulin-like receptor, subfamily A (without TM domain), member 3 \\
\hline MARCKS & 2.4 & myristoylated alanine-rich protein kinase $C$ substrate \\
\hline RHOB & 1.7 & ras homolog gene family, member B \\
\hline RRAS & 1.9 & related RAS viral (r-ras) oncogene homolog \\
\hline SAMD4A & 2.6 & sterile alpha motif domain containing $4 \mathrm{~A}$ \\
\hline SLC3IA2 & 1.7 & solute carrier family 31 (copper transporters), member 2 \\
\hline TCN2 & 2.2 & transcobalamin II; macrocytic anemia \\
\hline TLRI & 1.6 & toll-like receptor I \\
\hline TNFAIP6 (TSG-6) & 2.1 & tumor necrosis factor, alpha-induced protein 6 \\
\hline TNFSFIO (TRAIL) & 2.3 & tumor necrosis factor (ligand) superfamily, member 10 \\
\hline TRAFDI (FLN29) & 2.0 & TRAF-type zinc finger domain containing I \\
\hline VDR & 1.6 & vitamin $D(1,25$ - dihydroxyvitamin D3) receptor \\
\hline
\end{tabular}

Genes are significantly induced at day 3 but either not induced at any other time point, or day 3 fold change is at least $20 \%$ higher than other days.

\section{Patient Variation}

In both this study, and our previous one [2], we noted considerable variability in the initial levels of gene expression among subjects. Thus both studies were designed to examine the changes from this baseline; such a design allowed robust detection of the effects of interferon, and as noted above most changes were consistent between the two studies (Table 7) The clinical results of this trial are

Table 6: Genes induced late

\begin{tabular}{|c|c|c|c|c|c|c|c|c|}
\hline Symbol & Day 3 & Day 6 & Day 10 & Day 13 & Day 27 & Day 42 & Day 70 & Description \\
\hline CAI & -1.4 & 1.1 & 3.8 & 8.9 & 13.9 & 15.2 & 21.2 & carbonic anhydrase I \\
\hline FKBP8 & 1.2 & -1.1 & 1.4 & 2.7 & 2.1 & 2.7 & 3.5 & FK506 binding protein $8,38 \mathrm{kDa}$ \\
\hline GYPA & 1.5 & 1.3 & 4.5 & 8.4 & 14.7 & 15.5 & 17.3 & glycophorin A (MNS blood group) \\
\hline GYPB & -1.1 & -1.1 & 1.7 & 2.9 & 4.8 & 4.4 & 5.0 & glycophorin B (MNS blood group) \\
\hline GYPB & 1.2 & -1.0 & 2.4 & 4.5 & 6.0 & 6.5 & 7.5 & glycophorin B (MNS blood group) \\
\hline GYPB///GYPE & -1.1 & -1.0 & 1.5 & 2.7 & 3.2 & 3.3 & 3.7 & glycophorin B (MNS blood group)///glycophorin E \\
\hline HBD & -1.1 & -1.0 & 2.8 & 4.8 & 7.6 & 7.0 & 9.4 & hemoglobin, delta \\
\hline HBG I///HBG2 & -1.2 & -1.2 & 1.6 & 2.5 & 4.7 & 4.7 & 6.5 & hemoglobin, gamma $A / / /$ hemoglobin, gamma $G$ \\
\hline HBG2 & -1.2 & -1.3 & 1.8 & 2.5 & 5.0 & 5.0 & 6.8 & hemoglobin, gamma G \\
\hline HISTIH3H & 1.5 & 1.5 & 2.0 & 1.4 & 1.8 & 1.9 & 2.8 & histone cluster I, $\mathrm{H} 3 \mathrm{~h}$ \\
\hline LCN2 & 1.8 & 1.3 & 2.6 & 1.9 & 1.8 & 1.8 & 2.8 & lipocalin 2 (oncogene 24p3) \\
\hline MYL4 & 1.0 & 1.1 & 1.4 & 1.9 & 2.5 & 2.5 & 3.2 & myosin, light chain 4 , alkali; atrial, embryonic \\
\hline MYL4 & -1.0 & -1.1 & 1.4 & 2.2 & 2.9 & 3.2 & 3.7 & myosin, light chain 4 , alkali; atrial, embryonic \\
\hline SLCI4AI & -1.2 & 1.1 & 1.2 & 1.9 & 1.9 & 2.1 & 2.2 & $\begin{array}{l}\text { solute carrier family I } 4 \\
\text { (urea transporter), member I (Kidd blood group) }\end{array}$ \\
\hline TAL I & I.I & -1.3 & 1.4 & 1.6 & 2.1 & 1.9 & 2.7 & T-cell acute lymphocytic leukemia I \\
\hline TRIM58 & 1.7 & -1.1 & 2.5 & 2.6 & 4.0 & 3.3 & 4.2 & tripartite motif-containing 58 \\
\hline
\end{tabular}

Values in italics not significant when compared to base line. 


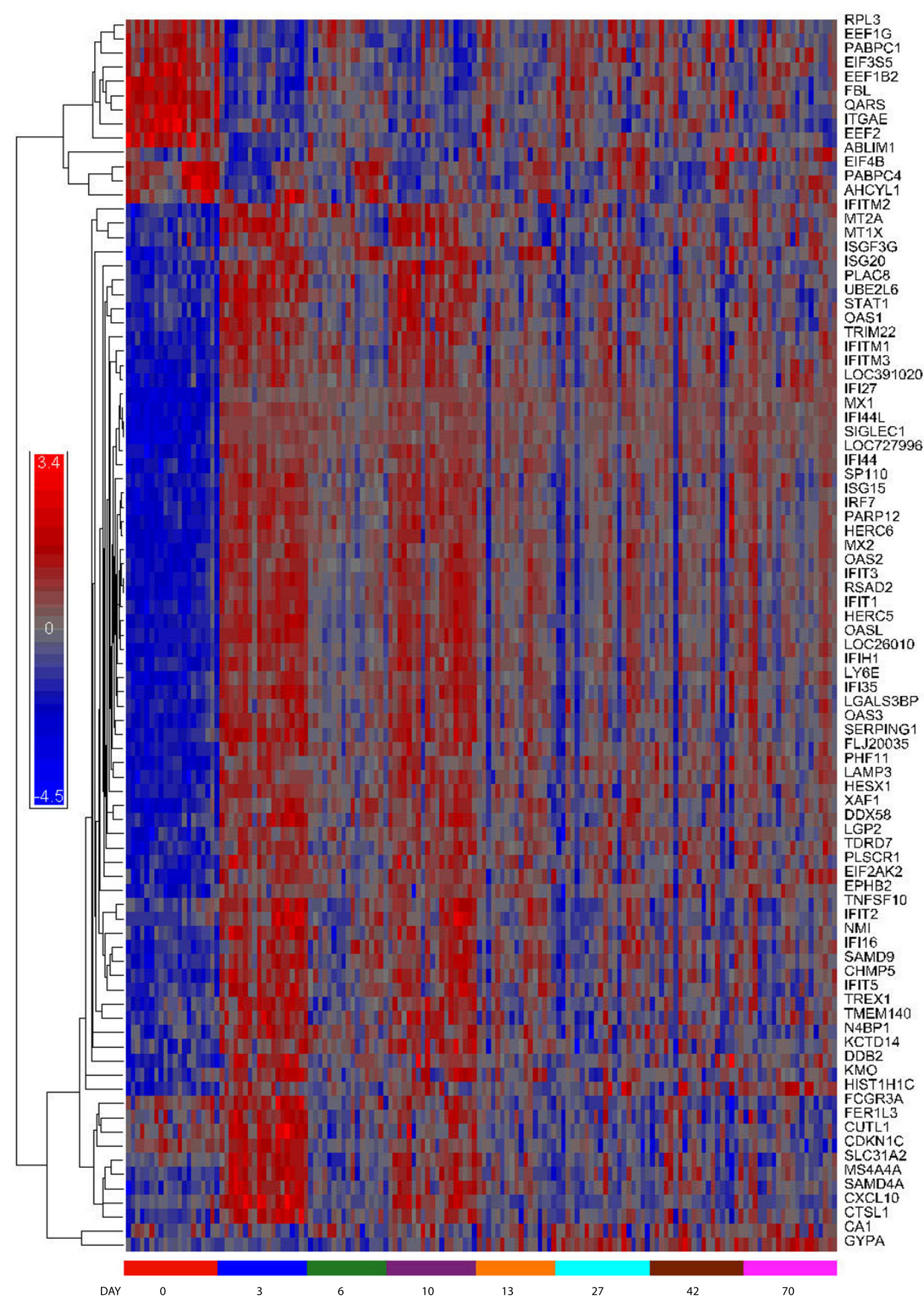

Figure 2

To illustrate the pattern of expression across time-points, data from the top 90 genes (by p-value) across all time points were clustered by Pearson Dissimilarity. Arrays (horizontal axis) are arranged in the order of time point (day) and within each time point by Non-Responder(NR) and Responder (R) as determined by viral titer at week 72 (final response in table 2). Expression values were normalized after clustering. 
Top 10 Differentially Expressed Genes

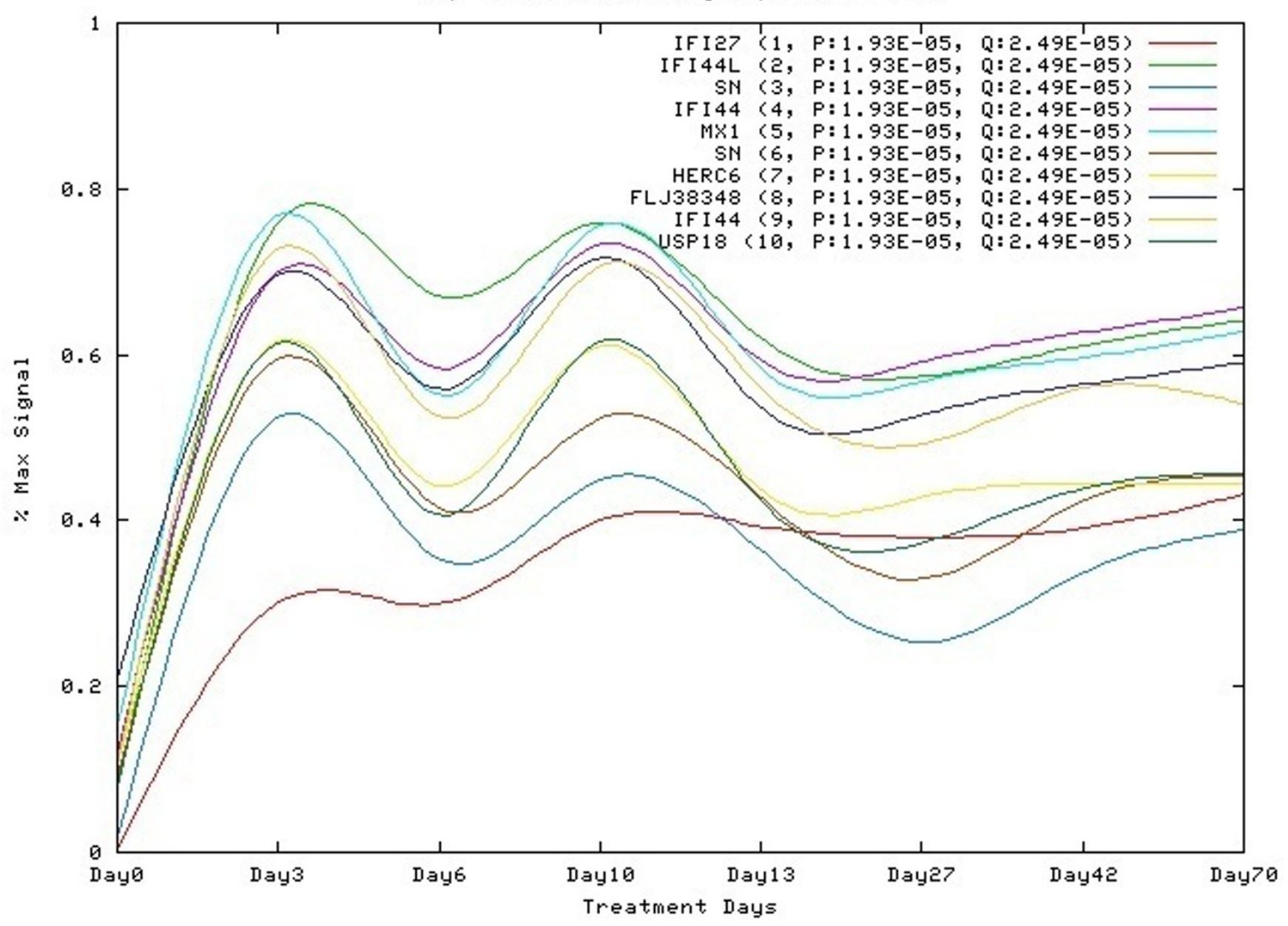

Figure 3

Gene expression profile over time of the 10 genes most differentially expressed, plotted as percentage of maximum signal with points were connected by natural cubic splines.

similar to previously reported trials in genotype I naïve patients $[1,2,7,8,50]$. The sustained viral response rate (SVR) was approximately $35 \%$. Only three patients showed a rapid response to interferon/ribavirin therapy, with an immediate decrease in viral titer. Ten patients showed no decrease in virus titer, and 7 showed a biphasic decrease. However the rate of initial viral decrease for the 7 patients with a biphasic curve was not predictive of final response in this small study. Two patients showed a return of virus at week 42 although one had cleared at week 10 the other by week 12 . Perhaps HCV can normally interfere with the interferon response through binding to RIG-I $[51,52]$ and the mutated virus is the exception and sensitive to interferon treatment. This is supported by recent work in which it has been shown there is more variability in RNA sequence in virus from responders than in nonresponders[53]. The occurrence of relapsers could be due to reversion of such " mutated" virus to wild type and restoration of resistance to treatment. The presence of relapsers also indicates that virus is "hiding" in either the liver or cells of the immune system or is present at nondetectable levels in the serum.

\section{Conclusion}

We have used multiple time points to measure gene expression. It is obvious from our data that a single measurement might give misleading data on gene expression and thus mechanism of action of the drug combination. This can be seen in particular with genes that are only transiently expressed, or that vary during treatment. Because both this study and the earlier Virahep C study [2] show a peak in the effects of interferon within the first 3 days after interferon, and a decline toward baseline before the next injection, it suggests that treatment more fre- 
Table 7: Comparison of fold changes between Pegaysy and Peg-intron at day 3

\begin{tabular}{|c|c|c|c|c|}
\hline Gene Symbol & Probe Set ID & Gene Title & Pegasys ${ }^{1}$ & PegIntron ${ }^{2}$ \\
\hline $\mathrm{IFI} 27$ & 2024II_at & interferon, alpha-inducible protein 27 & 46.6 & 73.3 \\
\hline SIGLECI & 219519_s_at & sialic acid binding Ig-like lectin I, sialoadhesin & 15.7 & 27.1 \\
\hline CCL2 & 216598_s_at & chemokine ( $\mathrm{C}-\mathrm{C}$ motif) ligand 2 & 15.1 & 13.4 \\
\hline RSAD2 & 213797_at & radical S-adenosyl methionine domain containing 2 & 11.7 & 12.8 \\
\hline IFITI & 203153_at & interferon-induced protein with tetratricopeptide repeats I & 11.3 & 12.2 \\
\hline HESXI & 211267_at & HESX homeobox I & 14.7 & 11.5 \\
\hline IFI44L & 204439_at & interferon-induced protein 44 -like & 6.5 & 10.1 \\
\hline USPI8 & 219211_at & ubiquitin specific peptidase $18 / / /$ similar to ubiquitin specific peptidase 18 & 5.6 & 7.4 \\
\hline IFIT3 & 204747_at & interferon-induced protein with tetratricopeptide repeats 3 & 7.6 & 7.1 \\
\hline IFI44 & 214059_at & Interferon-induced protein 44 & 4.8 & 7.1 \\
\hline ISGI5 & 205483_s_at & ISGI 5 ubiquitin-like modifier & 6.2 & 6.8 \\
\hline SIGLECI & 44673_at & sialic acid binding Ig-like lectin I, sialoadhesin & 5.5 & 6.4 \\
\hline LAMP3 & 205569_at & lysosomal-associated membrane protein 3 & 4.1 & 6.0 \\
\hline IFI44 & 214453_s_at & interferon-induced protein 44 & 4.5 & 6.0 \\
\hline HERC6 & 219352_at & hect domain and RLD 6 & 4.2 & 5.9 \\
\hline MXI & 202086_at & myxovirus (influenza virus) resistance I, interferon-inducible protein p78 (mouse) & 4.3 & 5.0 \\
\hline SERPINGI & 200986_at & $\begin{array}{l}\text { serpin peptidase inhibitor, clade } \mathrm{G} \\
\text { ( } \mathrm{Cl} \text { inhibitor), member I, (angioedema, hereditary) }\end{array}$ & 4.0 & 4.9 \\
\hline OASL & 205660_at & 2'-5'-oligoadenylate synthetase-like & 4.9 & 4.6 \\
\hline HERC5 & 219863_at & hect domain and RLD 5 & 4.4 & 4.5 \\
\hline OAS3 & 218400_at & 2'-5'-oligoadenylate synthetase $3,100 \mathrm{kDa}$ & 4.1 & 4.5 \\
\hline
\end{tabular}

'Fold-changes in Virahep C study []

2Fold-changes in this study.

quently than once a week, at least during the first month of treatment, might be more efficacious. The effects of more frequent treatment could be measured using the responses of a few key genes as a function of time. However it is also possible that the receptor sites are down regulated and require some time to be reactivated [54] or resynthesized. No major differences were found in gene induction or down regulation patterns between this study and that of Virahep C. Thus the location of the pegylation and structure of the interferon does not appear to be important in vivo, although it does alter the anti-viral activity in vitro [14]. This could suggest that the receptor sites for interferon are saturated in vivo, and that the activities once bound to the receptor are identical. It should be noted that the patients treated in this study received lower doses of interferon. We could find no relationship between response to therapy and gene induction in this trial, perhaps because of the very low number of rapid and sustained responders.

\section{Competing interests}

Dr. Paul Kwo is a Scientific Advisor to Schering- Plough.

\section{Authors' contributions}

This Ms was written and data interpreted by MWT. TT was employed as a bio-informaticist and together with JNM performed statistical analysis. HJE as head of the Center for Medical Genomics helped write the manuscript. PK ran the clinical study.

\section{Additional material}

\section{Additional file 1}

List of genes with significant differential expression for at least one time point

Click here for file

[http://www.biomedcentral.com/content/supplementary/14795876-6-66-S1.pdf]

\section{Additional file 2}

Comparison of fold changes for genes differentially expressed at day 3 for this study and the ViraHep C study

Click here for file

[http://www.biomedcentral.com/content/supplementary/14795876-6-66-S2.pdf]

\section{Acknowledgements}

We wish to thank Mary Ferris for the preparation of cells and the extraction of RNA.

This research was supported from a grant from Integrated Therapeutics (Schering Inc.) Microarrays were processed at the Center for Medical Genomics which is supported in part by a grant from the Indiana Genomics Initiative (INGEN, which is supported in part by The Lilly Endowment Inc.).

\section{References}

I. Conjeevaram HS, Fried MW, Jeffers LJ, Terrault NA, Wiley-Lucas TE, Afdhal N, Brown RS, Belle SH, Hoofnagle JH, Kleiner DE, Howell CD: Peginterferon and ribavirin treatment in African American and Caucasian American patients with hepatitis C genotype I. Gastroenterology 2006, 13 I:470-477. 
2. Taylor MW, Tsukahara T, Brodsky L, Schaley J, Sanda C, Stephens MJ, McClintick JN, Edenberg HJ, Li L, Tavis JE, et al:: Changes in gene expression during pegylated interferon and ribavirin therapy of chronic hepatitis $\mathbf{C}$ virus distinguish responders from nonresponders to antiviral therapy. J Virol 2007, 81:339I-340I.

3. Alter MJ: Epidemiology of hepatitis $\mathbf{C}$ virus infection. World J Gastroenterol 2007, I3:2436-244 I.

4. Fried MW, Shiffman ML, Reddy KR, Smith C, Marinos G, Goncales FL Jr, Haussinger D, Diago M, Carosi G, Dhumeaux D, et al.: Peginterferon alfa-2a plus ribavirin for chronic hepatitis $C$ virus infection. N Engl J Med 2002, 347:975-982.

5. Kozlowski A, Charles SA, Harris JM: Development of pegylated interferons for the treatment of chronic hepatitis C. BioDrugs 200I, I 5:419-429.

6. Kamal SM, Fehr J, Roesler B, Peters T, Rasenack JW: Peginterferon alone or with ribavirin enhances HCV-specific CD4 T-helper I responses in patients with chronic hepatitis C. Gastroenterology 2002, I 23:1070-1083.

7. Zeuzem S, Herrmann E, Lee JH, Fricke J, Neumann AU, Modi M, Colucci G, Roth WK: Viral kinetics in patients with chronic hepatitis $C$ treated with standard or peginterferon alpha2a. Gastroenterology 200I, I 20:1438-1447.

8. Manns MP, McHutchison JG, Gordon SC, Rustgi VK, Shiffman M, Reindollar R, Goodman ZD, Koury K, Ling M, Albrecht JK: Peginterferon alfa-2b plus ribavirin compared with interferon alfa-2b plus ribavirin for initial treatment of chronic hepatitis C: a randomised trial. Lancet 200I, 358:958-965.

9. Shiffman ML: Pegylated interferons: what role will they play in the treatment of chronic hepatitis C? Curr Gastroenterol Rep 200I, 3:30-37.

10. Glue P, Fang JW, Rouzier-Panis R, Raffanel C, Sabo R, Gupta SK, Salfi $M$, Jacobs S: Pegylated interferon-alpha2b: pharmacokinetics, pharmacodynamics, safety, and preliminary efficacy data. Hepatitis C Intervention Therapy Group. Clin Pharmacol Ther 2000, 68:556-567.

II. Grace MJ, Lee S, Bradshaw S, Chapman J, Spond J, Cox S, Delorenzo M, Brassard D, Wylie D, Cannon-Carlson S, et al.: Site of pegylation and polyethylene glycol molecule size attenuate interferonalpha antiviral and antiproliferative activities through the JAK/STAT signaling pathway. J Biol Chem 2005, 280:6327-6336.

12. Grace M, Youngster S, Gitlin G, Sydor W, Xie L, Westreich L, Jacobs $S$, Brassard D, Bausch J, Bordens R: Structural and biologic characterization of pegylated recombinant IFN-alpha2b. J Interferon Cytokine Res 200I, 21:I 103-III5.

13. Certa U, Wilhelm-Seiler M, Foser S, Broger C, Neeb M: Expression modes of interferon-alpha inducible genes in sensitive and resistant human melanoma cells stimulated with regular and pegylated interferon-alpha. Gene 2003, 3 | 5:79-86.

14. Grace MJ, Cutler D: Pegylating IFNs at his-34 improves the in vitro antiviral activity through the JAK/STAT pathway. Antivir Chem Chemother 2004, I5:287-297.

15. Brassard DL, Delorenzo MM, Cox S, Leaman DW, Sun Y, Ding W, Gavor S, Spond J, Goodsaid F, Bordens R, Grace MJ: Regulation of gene expression by pegylated IFN-alpha2b and IFN-alpha2b in human peripheral blood mononuclear cells. J Interferon Cytokine Res 2004, 24:455-469.

16. Kim SH, Cohen B, Novick D, Rubinstein M: Mammalian type I interferon receptors consists of two subunits: IFNaRI and IFNaR2. Gene 1997, 196:279-286.

17. Schindler C: Cytokines and JAK-STAT signaling. Exp Cell Res 1999, 253:7-14.

18. Brierley MM, Fish EN: Review: IFN-alpha/beta receptor interactions to biologic outcomes: understanding the circuitry. J Interferon Cytokine Res 2002, 22:835-845.

19. Brierley MM, Fish EN: Stats: multifaceted regulators of transcription. J Interferon Cytokine Res 2005, 25:733-744.

20. van Boxel-Dezaire AH, Rani MR, Stark GR: Complex modulation of cell type-specific signaling in response to type I interferons. Immunity 2006, 25:361-372.

21. van Boxel-Dezaire AH, Stark GR: Cell type-specific signaling in response to interferon-gamma. Curr Top Microbiol Immunol 2007, 316:119-154.

22. Der SD, Zhou A, Williams BR, Silverman RH: Identification of genes differentially regulated by interferon alpha, beta, or gamma using oligonucleotide arrays. Proc Natl Acad Sci USA 1998, 95:15623-15628.
23. Taylor MW, Grosse WM, Schaley JE, Sanda C, Wu X, Chien SC, Smith F, Wu TG, Stephens M, Ferris MW, et al.: Global effect of PEGIFN-alpha and ribavirin on gene expression in PBMC in vitro. J Interferon Cytokine Res 2004, 24: I 07-I I8.

24. Tan H, Derrick J, Hong J, Sanda C, Grosse WM, Edenberg HJ, Taylor M, Seiwert S, Blatt LM: Global transcriptional profiling combination of type I and type II demonstrates the interferon enhances antiviral and immune responses at clinically relevant doses. J Interferon Cytokine Res 2005, 25( I0):632-649.

25. Sanda C, Weitzel P, Tsukahara T, Schaley J, Edenberg HJ, Stephens MA, McClintick JN, Blatt LM, Li L, Brodsky L, Taylor MW: Differential Gene Induction by Type I and Type II Interferons and Their Combination. J Interferon Cytokine Res 2006, 26:462-472.

26. Brodsky LI, Wahed AS, Li J, Tavis JE, Tsukahara T, Taylor MW: A novel unsupervised method to identify genes important in the anti-viral response: application to interferon/ribavirin in hepatitis C patients. PLoS ONE 2007, 2:e584.

27. McClintick JN, Edenberg HJ: Effect of filtering by Present call on analysis of microarray experiments. BMC Bioinformatics 2006, 7:49.

28. Storey JD, Xiao W, Leek JT, Tompkins RG, Davis RW: Significance analysis of time course microarray experiments. Proc Natl Acad Sci USA 2005, 102: I 2837-12842.

29. Benjamini YaHY: Controlling the false discovery rate: A practical andpowerful approach to multiple testing. Journal of the Royal Statistical Society B 1995, 57:289-300.

30. Su Al, Pezacki JP, Wodicka L, Brideau AD, Supekova L, Thimme R, Wieland S, Bukh J, Purcell RH, Schultz PG, Chisari FV: Genomic analysis of the host response to hepatitis $C$ virus infection. Proc Natl Acad Sci USA 2002, 99: I5669-15674.

3I. Ji X, Cheung R, Cooper S, Li Q, Greenberg HB, He XS: Interferon alfa regulated gene expression in patients initiating interferon treatment for chronic hepatitis C. Hepatology 2003, 37:610-62I.

32. de Veer MJ, Holko M, Frevel M, Walker E, Der S, Paranjape JM, Silverman RH, Williams BR: Functional classification of interferonstimulated genes identified using microarrays. J Leukoc Biol 200I, 69:912-920.

33. Lagging M, Romero Al, Westin J, Norkrans G, Dhillon AP, Pawlotsky JM, Zeuzem S, von Wagner M, Negro F, Schalm SW, et al.: IP-I 0 predicts viral response and therapeutic outcome in difficult-totreat patients with HCV genotype I infection. Hepatology 2006, 44:1617-1625.

34. Romero Al, Lagging M, Westin J, Dhillon AP, Dustin LB, Pawlotsky JM, Neumann AU, Ferrari C, Missale G, Haagmans BL, et al.: Interferon (IFN)-gamma-inducible protein-10: association with histological results, viral kinetics, and outcome during treatment with pegylated IFN-alpha $2 a$ and ribavirin for chronic hepatitis C virus infection. J Infect Dis 2006, 194:895-903.

35. Cotler SJ, Craft T, Ferris M, Morrisey M, McCone J, Reddy KR, Con$\operatorname{rad} \mathrm{A}$, Jensen DM, Albrecht J, Taylor MW: Induction of IL-IRa in resistant and responsive hepatitis $C$ patients following treatment with IFN-con I. J Interferon Cytokine Res 2002, 22:549-554.

36. Gibellini D, Re MC, Ponti C, Maldini C, Celeghini C, Cappellini A, La Placa M, Zauli G: HIV-I Tat protects CD4+ Jurkat T lymphoblastoid cells from apoptosis mediated by TNF-related apoptosis-inducing ligand. Cell Immunol 200I, 207:89-99.

37. Warke RV, Martin KJ, Giaya K, Shaw SK, Rothman AL, Bosch I: TRAIL is a novel antiviral protein against dengue virus. J Virol 2008, 82:555-564.

38. Wisniewski HG, Vilcek J: TSG-6: an IL-I/TNF-inducible protein with anti-inflammatory activity. Cytokine Growth Factor Rev 1997, 8:143-156.

39. Milner CM, Day AJ: TSG-6: a multifunctional protein associated with inflammation. J Cell Sci 2003, I I 6: |863-1873.

40. Landolfo S, Gariglio M, Gribaudo G, Lembo D: The Ifi 200 genes: an emerging family of IFN-inducible genes. Biochimie 1998, 80:72I-728

4I. Chen IF, Ou-Yang F, Hung JY, Liu JC, Wang H, Wang SC, Hou MF, Hortobagyi GN, Hung MC: AIM2 suppresses human breast cancer cell proliferation in vitro and mammary tumor growth in a mouse model. Mol Cancer Ther 2006, 5: I-7.

42. Cresswell KS, Clarke CJ, Jackson JT, Darcy PK, Trapani JA, Johnstone RW: Biochemical and growth regulatory activities of the HIN-200 family member and putative tumor suppressor protein, AIM2. Biochem Biophys Res Commun 2005, 326:417-424. 
43. Mashima R, Saeki K, Aki D, Minoda Y, Takaki H, Sanada T, Kobayashi $T$, Aburatani $H$, Yamanashi $Y$, Yoshimura A: FLN29, a novel interferon- and LPS-inducible gene acting as a negative regulator of toll-like receptor signaling. I Biol Chem 2005, 280:4|289-4I297.

44. Chang TS, Kim MJ, Ryoo K, Park J, Eom SJ, Shim J, Nakayama KI, Nakayama K, Tomita M, Takahashi K, et al.: p57KIP2 modulates stress-activated signaling by inhibiting c-Jun NH2-terminal kinase/stress-activated protein Kinase. J Biol Chem 2003, 278:48092-48098.

45. Watanabe H, Pan ZQ, Schreiber-Agus N, DePinho RA, Hurwitz J, Xiong Y: Suppression of cell transformation by the cyclindependent kinase inhibitor p57KIP2 requires binding to proliferating cell nuclear antigen. Proc Natl Acad Sci USA 1998, 95: I392- I397.

46. Lodish HF, Berk A, Zipursky SL, Matsudaira P, Baltimore D, Darnell JE: Molecular Cell Biology New York: W.H. Freeman and Company; 2000.

47. Dean L: Blood Groups and Red Cell Antigens. NCBI 2006.

48. Saito $H$, Tada S, Ebinuma $H$, Ishii $H$, Kashiwazaki K, Takahashi M, Tsukada N, Nishida J, Tanaka S, Shiozaki H, Hibi T: Role of erythrocytes as a reservoir for ribavirin and relationship with adverse reactions in the early phase of interferon combination therapy for chronic hepatitis C virus infections. J Clin Microbiol 2006, 44:3562-3568.

49. Russmann S, Grattagliano I, Portincasa P, Palmieri VO, Palasciano G: Ribavirin-induced anemia: mechanisms, risk factors and related targets for future research. Curr Med Chem 2006, | 3:335|-3357.

50. Reddy KR, Wright TL, Pockros PJ, Shiffman M, Everson G, Reindollar R, Fried MW, Purdum PP 3rd, Jensen D, Smith C, et al.: Efficacy and safety of pegylated (40-kd) interferon alpha-2a compared with interferon alpha-2a in noncirrhotic patients with chronic hepatitis C. Hepatology 200I, 33:433-438.

5I. Tasaka M, Sakamoto N, Itakura Y, Nakagawa M, Itsui Y, Sekine-Osajima $\mathrm{Y}$, Nishimura-Sakurai $\mathrm{Y}$, Chen $\mathrm{CH}$, Yoneyama M, Fujita T, et al.: Hepatitis $C$ virus non-structural proteins responsible for suppression of the RIG-I/Cardif-induced interferon response. J Gen Virol 2007, 88:3323-3333.

52. Johnson CL, Owen DM, Gale M Jr: Functional and therapeutic analysis of hepatitis C virus NS3.4A protease control of antiviral immune defense. J Biol Chem 2007, 282:10792-10803.

53. Donlin MJ, Cannon NA, Yao E, Li J, Wahed A, Taylor MW, Belle SH, Di Bisceglie AM, Aurora R, Tavis JE: Pretreatment sequence diversity differences in the full-length hepatitis $C$ virus open reading frame correlate with early response to therapy. J Virol 2007, 81:82II-8224.

54. Ito $\mathrm{K}$, Tanaka $\mathrm{H}$, Ito $\mathrm{T}$, Sultana TA, Kyo T, Imanaka $\mathrm{F}$, Ohmoto $\mathrm{Y}$, Kimura A: Initial expression of interferon alpha receptor 2 (IFNAR2) on CD34-positive cells and its down-regulation correlate with clinical response to interferon therapy in chronic myelogenous leukemia. Eur J Haematol 2004, 73:191-205.

Publish with Biomed Central and every scientist can read your work free of charge

"BioMed Central will be the most significant development for disseminating the results of biomedical research in our lifetime. "

Sir Paul Nurse, Cancer Research UK

Your research papers will be:

- available free of charge to the entire biomedical community

- peer reviewed and published immediately upon acceptance

- cited in PubMed and archived on PubMed Central

- yours - you keep the copyright

Submit your manuscript here:

http://www.biomedcentral.com/info/publishing_adv.asp
BioMedcentral 